\title{
$1 \mathrm{~g}$ 진동대 실험 및 등가정적해석을 이용한 억지말뚝의 사면안정 내진보강 효과 연구
}

\author{
A Study on Seismic Retrofit Design of the Stabilized Piles \\ by $1 \mathrm{~g}$ Shaking Table Tests and Pseudo-static Analysis \\ 한진태* · 조종석** · 유민택*** • 이승현***** \\ Han, Jin-Tae $\cdot$ Cho, Jong-Suck $\cdot$ Yoo, Min-Taek $\cdot$ Lee, Seung-Hyun
}

\begin{abstract}
Korea has about $70 \%$ of its land classified as the mountain area, which has led to cut-slope being the result of substantial road and railway construction. However, there is currently a lack of research about the seismic retrofit design of a slope, even though many earthquakes have recently occurred at home and abroad. In this study, in order to investigate the stabilizing effect of piles against sliding during an earthquake, a series of $1 \mathrm{~g}$ shaking table tests and pseudo-static analyses were carried out. As a result, the stabilizing effect of piles against sliding during an earthquake was verified by the $1 \mathrm{~g}$ shaking table tests and the most effective result from the pseudo-static analyses was that the installation of the piles on the central part of the slope, where the failure surface included piles unlike the lower part and upper part of the slope. Furthermore, when the pile was installed on the central part of the slope, the change of the safety factor depending on the distance between the center of two piles was evaluated.
\end{abstract}

Key words : $1 \mathrm{~g}$ shaking table test, Seismic retrofit design, TALREN analysis Pseudo-static analysis, stabilized pile

\section{요 지}

국토의 $70 \%$ 이상이 산지인 국내 지형 조건에서 도로, 철도 등 크고 작은 건설 공사에서는 필연적으로 사면이 형성된다. 그 러나, 최근 국내외적으로 빈번히 발생하는 지진에 대한 사면안정 보강공법에 대한 연구는 전무한 실정이다. 이에 본 연구에서는 $1 \mathrm{~g}$ 진동대 실험 및 등가정적해석을 이용하여 사면의 내진 보강공법으로써 억지말뚝의 적용성을 평가하고, 억지말뚝이 적용된 사면 및 억지말뚝의 지진시 거동을 분석하였다. $1 \mathrm{~g}$ 진동대 실험 결과로부터, 억지말뚝 보강 사면의 지진시 사면파괴 억지효과 를 검증하였으며, 등가정적해석을 통해 억지 말뚝을 사면 하부 또는 상부보다 사면 파괴면의 중앙부에 말뚝을 설치했을 때 사 면파괴 억지효과가 가장 큼을 알 수 있었다. 또한, 말뚝이 사면 중앙부에 설치되었을 경우, 말뚝의 중심 간격에 따른 안전율 변화를 등가정적해석으로부터 분석하였다.

핵심용어 : $1 \mathrm{~g}$ 진동대 실험, 내진 보강 설계, TALREN 해석, 등가정적해석, 억지말뚝

\section{1. 서 론}

최근 한반도 인근에서의 빈번한 지진발생으로 인하여 국내 토목구조물은 직간접적으로 지진의 영항을 받을 확률이 점점 높아지고 있다. 그 중에서 토목 구조물 중 큰 비중을 차지하 고 지진 파괴시에 큰 인명 피해가 예상되는 절성토부 사면의 내진 성능에 대한 검토가 중요하다. 자연사면이나 굴착사면, 그리고 도로제방이나 흙댐과 같은 성토사면에서 흙은 중력, 간극수압, 지진 등의 작용을 받아 하향으로 무너지려고 하는 경향이 있다. 이러한 사면운동으로 인한 피해는 넓은 지역을
황폐화시키며, 사면에 인접한 구조물들의 안정성을 위협할 뿐 만 아니라 많은 인명손실을 초래하기도 한다. 따라서 사면의 안정을 확보하는 것은 이러한 경제적, 사회적 피해를 고려할 때 매우 중요한 문제이다. 평상시 안정성이 충분히 확보된 사면의 경우에도 지진으로 인하여 지반의 관성력이 발생하게 되고, 이로 인해 수평 변위가 증가하면 사면 파괴가 발생할 수 있기 때문에 지진시의 사면 거동 및 사면의 전단변형을 억제하기 위한 내진 공법에 대한 연구를 통한 대처가 요구된 다.

사면의 전단변형을 감소시키는 가장 직접적이고 적극적인

*정회원 · 서울대학교 건설환경공학부 BK 계약교수 (E-mail : jimmy76@snu.ac.kr)

**UC Davis 토목공학과 박사과정

***서울대학교 건설환경공학부 박사과정

****선문대학교 토목공학과 부교수 (교신저자) 
방법으로 억지말뚝 공법이 있다. 억지말뚝 공법은 활동 토체 를 관통하여 부동 지반까지 말뚝을 설치하여 사면의 활동 하 중을 말뚝을 통해 부동 지반에 전달시키는 공법이다. 타공법 들과 비교하여 지중 깊은 곳까지 활동이 발생하는 중규모 혹 은 대규모 산사태에 적용할 수 있다는 장점을 가지고 있다 (홍원표 등, 2003; 송영석, 2004). 따라서, 지진에 의해 대규 모 산사태가 예상되는 경우 억지말뚝이 사면의 내진 보강을 위해 유용하게 쓰일 수 있으며, 이미 국내 일부 내진설계지 침(대한주택공사, 1999)에 소개되어 있다. 다만, 지금까지의 연구는 주로 정적 설계 방법에 대해서만 이루어져왔다(Ito et al., 1981; Ito et al., 1982; 정상섬 등, 2003; 홍원표 등, 2005; 이승호, 2005). 이에 본 연구에서는 $1 \mathrm{~g}$ 진동대 실험 및 등가정적해석을 이용하여 지진 하중하에서 억지말뚝이 적 용된 사면과 억지말뚝 자체의 지진시 거동을 분석하고 사면 의 내진 보강공법으로써 억지말뚝의 적용성을 평가하고자 한 다.

\section{2. $1 \mathrm{~g}$ 진동대 모형 실험}

\section{1 실험 조건}

$1 \mathrm{~g}$ 진동대 실험을 위하여 2축 진동대가 사용되었으며 그 크기는 $2 \mathrm{~m} \times 2 \mathrm{~m}$ 이다. 2축 진동대의 최대 가속도, 최대 진동 수는 각각 $1 \mathrm{~g}$ 와 $50 \mathrm{~Hz}$ 이다. 주문진 표준사를 사용하여 모형 사면을 제작하였으며, 주문진 표준사의 유효입경 $\mathrm{D}_{10}$ 은 $0.38 \mathrm{~mm}$, 평균입경 $\mathrm{D}_{50}$ 은 $0.57 \mathrm{~mm}$, 균등계수 $\mathrm{Cu}$ 는 1.58 , 비 중은 2.62 , 그리고 최대 - 최소 건조단위중량은 각각 15.99 $\mathrm{kN} / \mathrm{m}^{3}$ 과 $13.05 \mathrm{kN} / \mathrm{m}^{3}$ 이다.

실험에 사용된 토조는 길이 $105 \mathrm{~cm}$, 폭 $44 \mathrm{~cm}$, 높이 $60 \mathrm{~cm}$ 로 두께 $2 \mathrm{~cm}$ 의 아크릴 판으로 제작하였고, 진동방향의 토조의 양 단면에는 진동시 경계 효과를 줄이기 위해 $5 \mathrm{~cm}$ 두께의 스편지를 설치하였다. 모형 사면지반은 그림 1 과 같 이 사면의 높이는 $25 \mathrm{~cm}$, 경사는 $1: 1.5$ (경사각 $=33.7^{\circ}$ ) 그리 고 사면의 깊이는 $30 \mathrm{~cm}$ 로 조성하였다. 사면 하부는 상대밀 도 $80 \%$ 로 조밀하게 조성하였는데, 이를 위해 $0.4 \mathrm{~g}, 10 \mathrm{~Hz}$ 의 정현파를 이용하여 $12.5 \mathrm{~cm}$ 씩 사면 높이 $25 \mathrm{~cm}$ 까지 1 분간 진동다짐을 하였으며, 다짐 후 상부 느슨한 지반 조성을 위 하여 느슨한 지반이 놓일 부분을 절토하였다. 상대밀도 $38 \%$

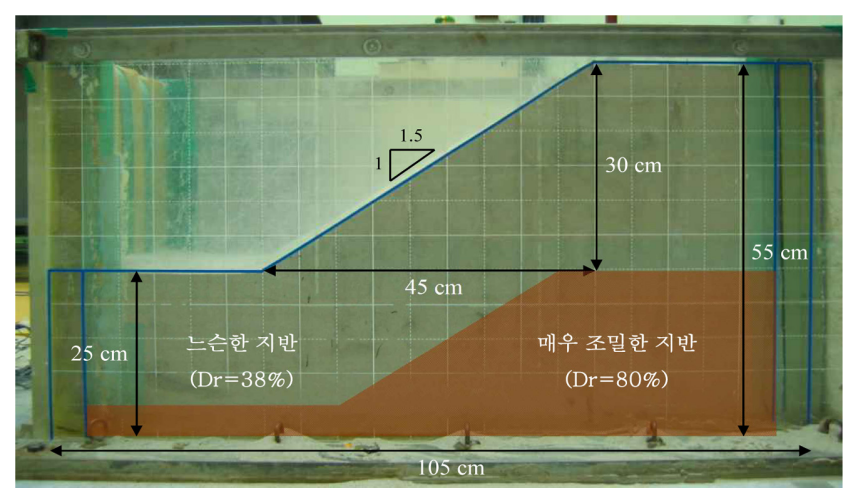

그림 1. 모형 사면지반 조성

표 1. 실험에 사용된 모형말뚝의 재질

\begin{tabular}{|c|c|}
\hline 재질 & 알루미늄 합금 \\
\hline 길이 $(\mathrm{L})$ & $300 \mathrm{~mm}$ \\
\hline 외경(D) $(\mathrm{mm}$ \\
\hline 두께(t) & $22 \mathrm{~mm}$ \\
\hline 탄성계수(E) & $67.82 \mathrm{GPa}$ \\
\hline 휨강성 $(\mathrm{EI})$ & $247.206 \mathrm{~N} \cdot \mathrm{m}^{2}$ \\
\hline
\end{tabular}

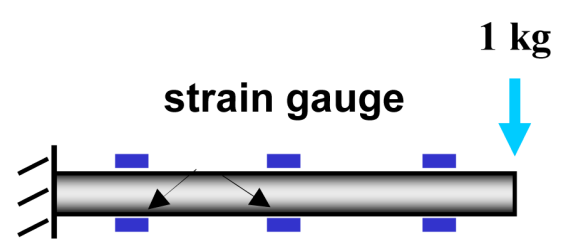

그림 2. 탄성계수를 구하기 위한 one point loading test

의 상부 느슨한 지반은 진동시 사면파괴를 용이하게 하기 위 하여 주문진 표준사를 천천히 강사하여 느슨하게 조성하였다.

모형말뚝은 길이 $300 \mathrm{~mm}$, 외경 $22 \mathrm{~mm}$, 두께 $1 \mathrm{~mm}$ 의 알 루미늄 관으로 제작하였으며, 제원은 표 1과 같다. 실험에 사 용된 모형말뚝의 정확한 탄성계수 $(\mathrm{E})$ 를 구하기 위해 그림 2 와 같이 one point loading test를 실시하였으며 탄성계수 값은 $67.82 \mathrm{GPa}$ 로 계산되었다. 말뚝에 발생하는 휨모멘트를 측정하기 위해 6개의 스트레인 게이지를 부착하였으며 게이 지의 부착 위치는 말뚝두부로부터 각각 $5 \mathrm{~cm}, 15 \mathrm{~cm}, 25 \mathrm{~cm}$ 이다. 또한 말뚝두부의 수평변위를 측정하기 위해 LVDT를 설치하였다. 모형말뚝과 계측기 설치 모습은 그림 3 과 같다.
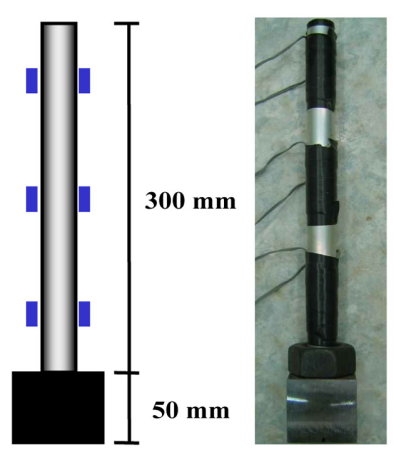

(a) 모형말뚝과 부착된 스트레인 게이지

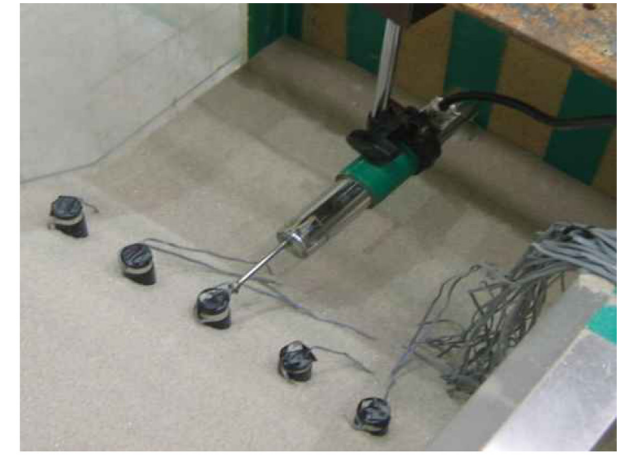

(b) 말뚝에 설치된 LVDT

그림 3. 모형말뚝과 계측기 설치 모습 


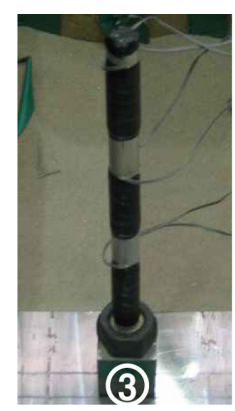

(a) 단말뚝

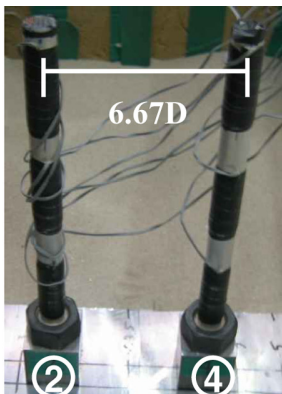

(b) C.T.C. $6.67 \mathrm{D}$

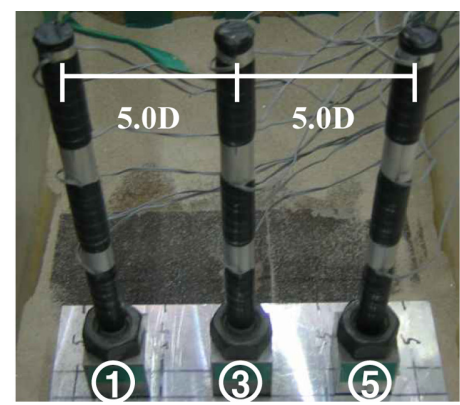

(c) C.T.C. $5 \mathrm{D}$

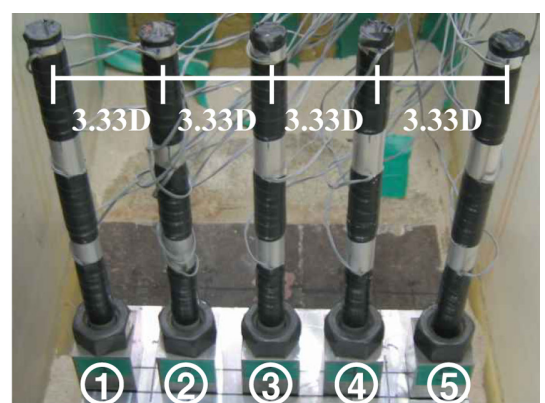

(d) C.T.C. $3.33 \mathrm{D}$

그림 4. 말뚝중심간격(C.T.C.)을 고려한 말뚝의 설치모습

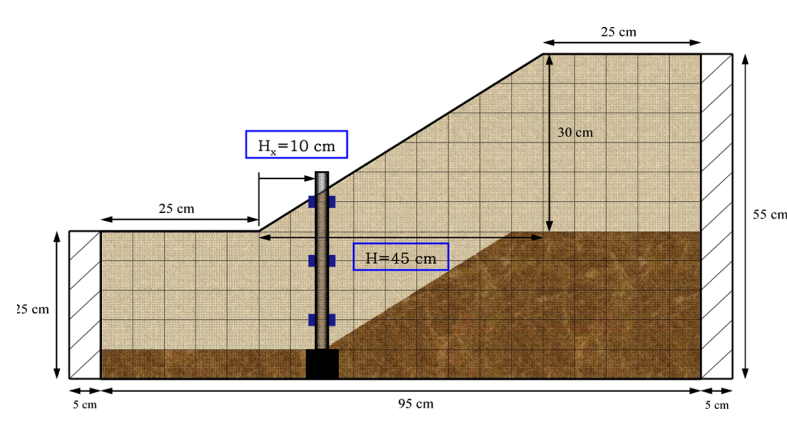

(a) 사면 하부, $\mathrm{Hx} / \mathrm{H}=0.22$

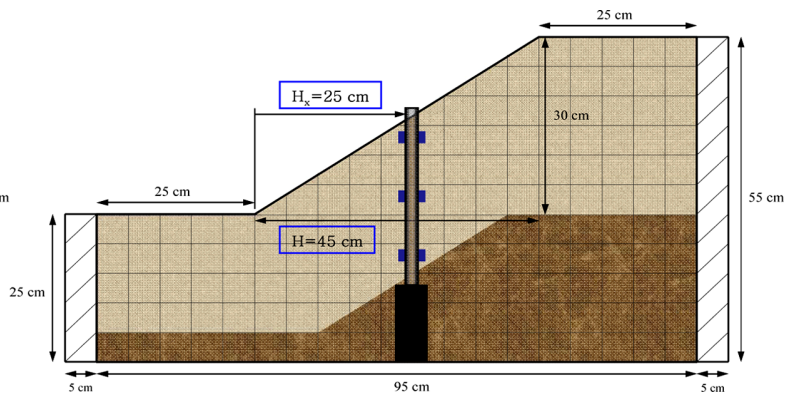

(b) 사면 중앙부, $\mathrm{Hx} / \mathrm{H}=0.56$

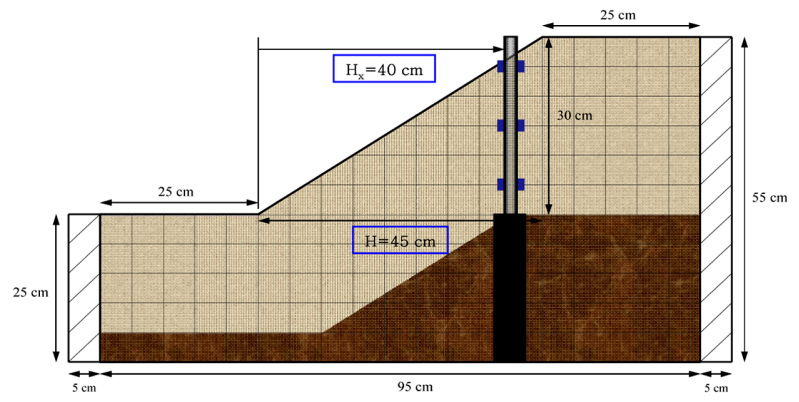

(c) 사면 상부, $\mathrm{Hx} / \mathrm{H}=0.89$

그림 5. 말뚝 설치위치

말뚝 설치시 암반에 근입된 억지말뚝을 모사하기 위하여 모 형말뚝의 지점 경계조건은 하부는 고정단, 상부는 자유단으로 하였으며 사각 철판을 이용하여 그림 3(a)와 같이 말뚝 하부 를 고정하였다.

본 실험에서는 억지말뚝의 설치간격에 따른 영향을 알아보 기 위하여 말뚝의 중심 간격(C.T.C. : Center To Center)을 $3.33 \mathrm{D}, 5 \mathrm{D}$, 그리고 $6.67 \mathrm{D}(\mathrm{D}$ :말뚝 직경)로 변화시키면서 실 험을 수행하였으며, 단말뚝만 설치한 경우에 대해서도 실험을 실시하였다. 중심 간격을 고려한 말뚝의 설치모습은 그림 4 와 같다. 실험에 사용된 말뚝은 단말뚝인 경우 1 개(3번 말뚝), 중 심 간격이 $6.67 \mathrm{D}$ 인 경우 2 개 $(2,4$ 번 말뚝), $5 \mathrm{D}$ 인 경우 3 개 $(1,3,5$ 번 말뚝), 그리고 $6.67 \mathrm{D}$ 인 경우 5 개 $(1,2,3,4,5$ 번 말뚝가 사용되었으며 좌, 우 양 끝에 있는 말뚝과 토조 사이의 거리도 말뚝의 중심 간격과 같도록 설치하였다.

또한, 억지말뚝의 설치위치에 따른 영향을 알아보기 위하여 그림 5 와 같이 말뚝의 설치위치를 사면 하부, 중앙부, 그리고 상부로 변화시키면서 실험을 수행하였다. 말뚝의 설치위치는 사면 선단과 말뚝 사이의 수평거리 $\mathrm{Hx}$ 와 사면 선단과 사면 정점부의 수평거리 $\mathrm{H}$ 와의 비 $(\mathrm{Hx} / \mathrm{H})$ 로 나타내었다. 사면 하부,

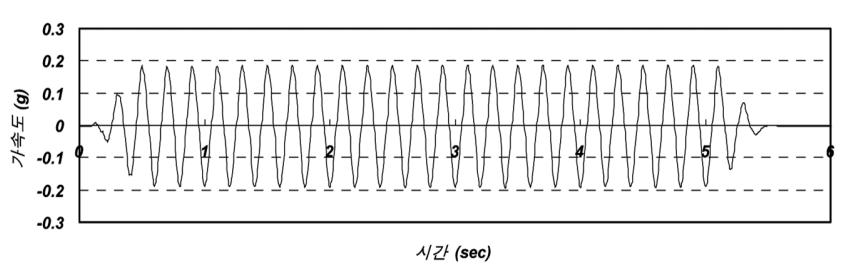

그림 6. 입력 지진파

중앙부, 그리고 상부에 설치된 말뚝의 위치 $(\mathrm{Hx} / \mathrm{H})$ 는 각각 $0.22,0.56$, 그리고 0.89 이다.

본 실험에 사용된 진동대 입력 지진파는 지반의 수평 변위 발생을 용이하게 하기 위하여, 국내 내진설계기준의 1 등급 붕 괴방지수준인 $0.154 \mathrm{~g}$ (한국지반공학회, 2006)보다 다소 큰 그 림 6 과 같은 최대진폭 $0.2 \mathrm{~g}, 5 \mathrm{~Hz}$ 주파수를 갖는 정현파를 사용하였다.

\section{2 실험 계획 및 방법}

$1 \mathrm{~g}$ 진동대 모형실험은 무보강 사면과 말뚝보강 사면으로 나누어 실시하였다. 무보강 사면에 대한 실험은 평상시 안정 성을 확보하고 있는 사면이 지진으로 인하여 지반의 수평 변 
표 $2.1 \mathrm{~g}$ 진동대 실험 조건

\begin{tabular}{|c|c|c|c|c|}
\hline 실험조건 & $\begin{array}{c}\text { 중심 간격 } \\
\text { (C.T.C) }\end{array}$ & $\begin{array}{c}\text { 설치위치 } \\
(\mathrm{Hx} / \mathrm{H})\end{array}$ & $\begin{array}{c}\text { 상대밀도 } \\
(\%)\end{array}$ & $\begin{array}{l}\text { 진동대 } \\
\text { 입력파 }\end{array}$ \\
\hline 무보강 & - & - & \multirow{13}{*}{$\begin{array}{c}\text { 매우 조밀 : } \\
80 \% \\
\text { 느슨 : } 38 \%\end{array}$} & \multirow{13}{*}{$\begin{array}{c}\text { 정현파 } \\
0.2 \mathrm{~g}, 5 \mathrm{~Hz}\end{array}$} \\
\hline \multirow{12}{*}{ 말뚝보강 } & \multirow{3}{*}{ 단말뚝 } & 0.22 & & \\
\hline & & 0.56 & & \\
\hline & & 0.89 & & \\
\hline & \multirow{3}{*}{$3.33 \mathrm{D}$} & 0.22 & & \\
\hline & & 0.59 & & \\
\hline & & 0.89 & & \\
\hline & \multirow{3}{*}{$5 \mathrm{D}$} & 0.22 & & \\
\hline & & 0.56 & & \\
\hline & & 0.89 & & \\
\hline & \multirow{3}{*}{$6.67 \mathrm{D}$} & 0.22 & & \\
\hline & & 0.56 & & \\
\hline & & 0.89 & & \\
\hline
\end{tabular}

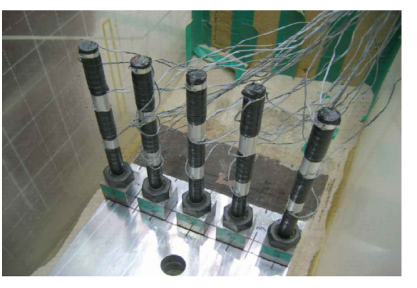

(a) 모형말뚝 설치

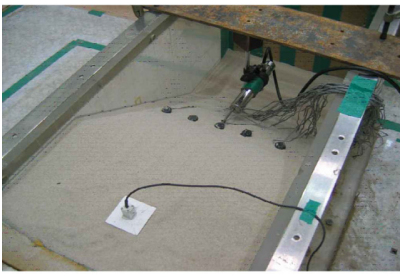

(c) 계측기 설치

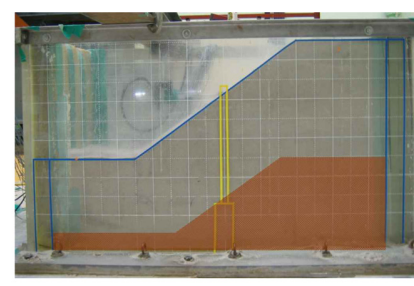

(b) 모형사면지반 조성

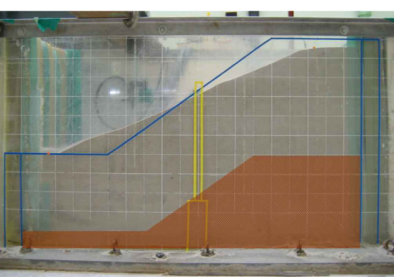

(d) 실험 후 사면경사 확인
그림 7. 말뚝보강 사면에 대한 실험순서

(말뚝보강사면, $5 \mathrm{D}, \mathrm{Hx} / \mathrm{H}=0.56$ )

위가 증가하면 사면파괴가 발생하는지 검증하기 위하여 실시 하였으며, 말뚝보강 사면에 대한 실험은 억지말뚝을 설치하여 지진시 억지말뚝으로 인한 사면파괴 억지효과를 분석하기 위 해 실시하였다. 사면안정을 위한 억지말뚝의 사면파괴 억지효 과는 말뚝의 설치위치, 중심 간격에 크게 영향을 받으므로 말뚝보강 사면에 대한 실험은 앞 절에서 언급한 바와 같이 말뚝의 설치위치와 중심 간격을 변화시키면서 실시하였다. 각 각의 설치위치 $(\mathrm{Hx} / \mathrm{H}=0.22,0.56$, 그리고 0.89$)$ 에 대해 중심 간격을 단말뚝, $3.33 \mathrm{D}, 5 \mathrm{D}$, 그리고 $6.67 \mathrm{D}$ 로 변화시키면서 실험을 수행하였다. 전체 실험조건은 표 2 와 같으며, 지반의 상대밀도와 진동대 입력파는 모든 조건의 실험에 대해서 동 일하게 적용하였다. 그림 7은 말뚝보강 사면에 대한 실험 순 서를 보여주고 있다.

\section{3. $1 \mathrm{~g}$ 진동대 모형 실험 결과 분석}

\section{1 사면경사 변화 비교}

말뚝보강 사면의 사면파괴 억지효과를 분석하기 위하여 진

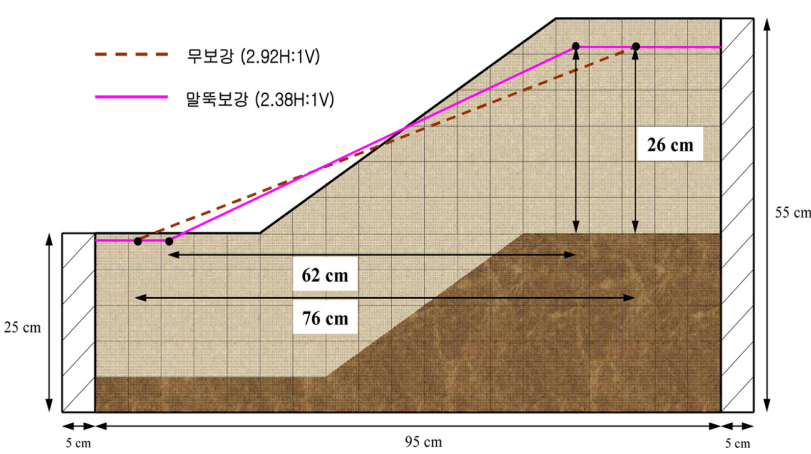

그림 8. 무보강 사면과 말뚝보강 사면의 사면경사 변화 비교

동후 무보강 사면과 말뚝보강 사면의 사면경사각과 지반거동 을 분석하였다. 무보강 사면의 경우 그림 8 에서 보는 바와 같이 실험 전과 비교하여 사면 선단은 $19 \mathrm{~cm}$ 의 지반흐름과 $1 \mathrm{~cm}$ 의 침하가 발생하였으며 사면 정점부는 지반흐름에 의해 $12 \mathrm{~cm}$ 만큼 뒤로 이동하였으며 $4 \mathrm{~cm}$ 의 침하가 발생하였다. 이 결과 무보강 사면의 경사는 진동전 $1: 1.5$ (경사각 $=33.7^{\circ}$ ) 에서 $1: 2.92$ (경사각 $=18.9^{\circ}$ )로 $44 \%$ 감소하였다.

무보강 사면과 달리 말뚝보강 사면은 사면 선단이 $14 \mathrm{~cm}$ 앞으로, 사면 정점부는 $3 \mathrm{~cm}$ 뒤로 이동하였으며 침하량은 무 보강 사면과 같은 결과를 나타내었다. 이 결과 말뚝보강 사 면의 경사는 진동전 $1: 1.5$ (경사각 $=33.7^{\circ}$ )에서 $1: 2.38$ (경사각 $=22.8^{\circ}$ )로 $32 \%$ 감소하였다. 말뚝보강 사면의 경우 진동후 관 찰한 사면경사 변화는 말뚝중심간격과 설치위치별로 큰 차이 를 보이지 않고 유사하게 관찰되었다. 실험 결과 말뚝보강 사면은 무보강 사면과 비교해 사면파괴 억지효과가 있음을 알 수 있었으나, 사면의 경사각 변화만으로는 말뚝중심간격과 설치위치에 따른 영항을 파악할 수 없었다. 따라서, 말뚝에 작용하는 모멘트와 말뚝의 변위를 통해 말뚝중심간격과 설치 위치에 따른 영항을 분석하였다.

\section{2 말뚝중심간격에 의한 영향}

\section{2 .1 최대 휨모멘트 결과}

말뚝에 부착된 스트레인 게이지를 통해 말뚝에 발생하는 휨모멘트를 계산하였다. 그림 9는 말뚝중심간격에 따른 깊이 별 최대 휨모멘트 결과를 보여주고 있다. 그림 9에서 볼 수 있듯이 모든 말뚝은 깊이가 증가할수록 휨모멘트가 증가함을 알 수 있다. $\mathrm{Hx} / \mathrm{H}=0.22,0.89$ 인 경우(그림 9(a), (c)) 말뚝중
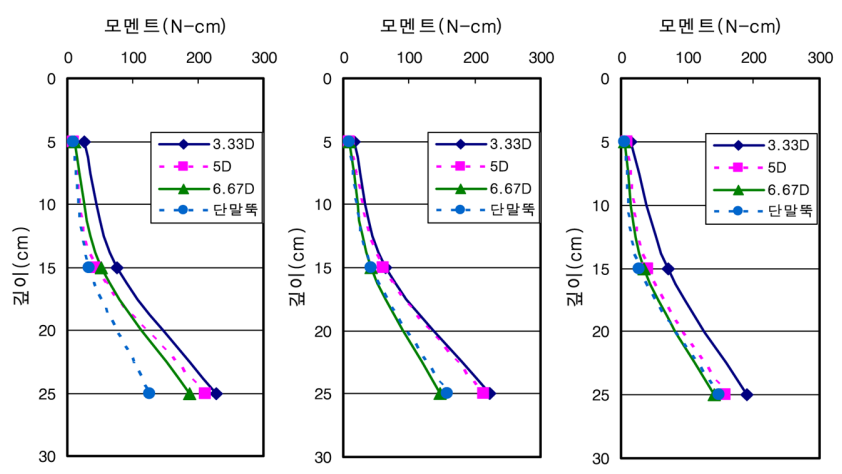

(a) $\mathrm{Hx} / \mathrm{H}=0.22$ (하부) (b) $\mathrm{Hx} / \mathrm{H}=0.56$ (중앙부) (c) $\mathrm{Hx} / \mathrm{H}=0.89$ (상부) 그림 9. 말뚝 C.T.C.에 따른 깊이별 최대 휨모멘트 $(\mathrm{N} \cdot \mathrm{cm})$ 


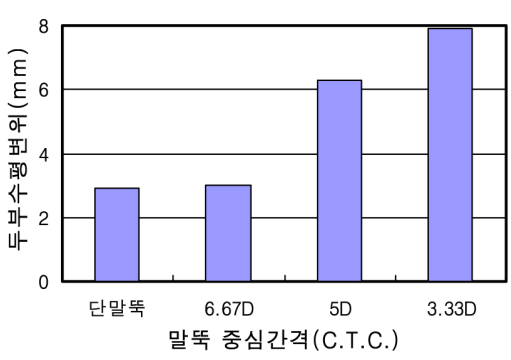

(a) $\mathrm{Hx} / \mathrm{H}=0.22$ (하부)

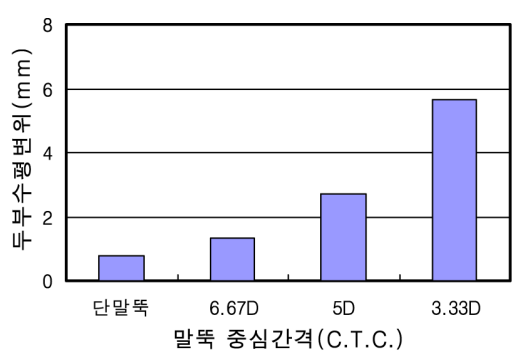

(b) $\mathrm{Hx} / \mathrm{H}=0.56$ (중앙부)

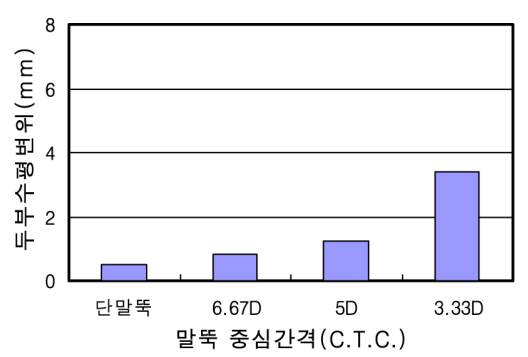

(c) $\mathrm{Hx} / \mathrm{H}=0.89$ (상부)

그림 10. 말뚝 C.T.C.에 따른 말뚝두부 수평 변위

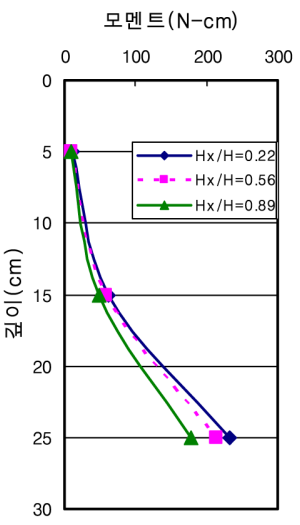

(a) 1 번 말뚝

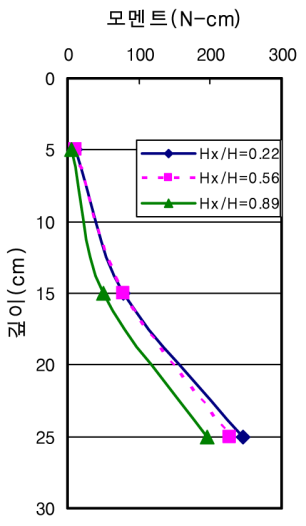

(b) 2 번 말뚝

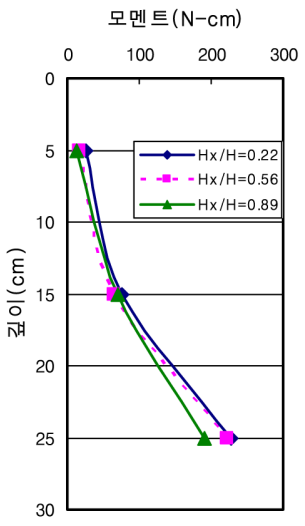

(c) 3 번 말뚝

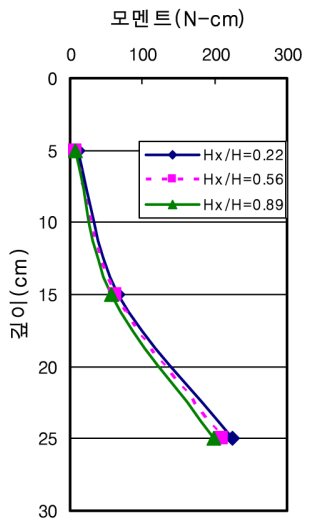

(d) 4 번 말뚝

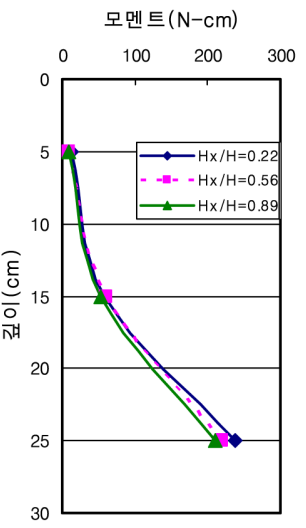

(e) 5 번 말뚝

그림 11. C.T.C. 3.33D인 경우 말뚝 설치위치에 따른 깊이별 최대 휨모멘트 $(\mathrm{N} \cdot \mathrm{cm})$

심간격이 단말뚝만 있는 조건에서 $3.33 \mathrm{D}$ 로 감소함에 따라 깊 이별 최대 휨모멘트는 증가하였다. $\mathrm{Hx} / \mathrm{H}=0.56$ 인 경우(그림 9(b)) 깊이 $15 \mathrm{~cm}$ 부터 단말뚝의 최대 휨모멘트가 중심 간격 $6.67 \mathrm{D}$ 일 때 보다 약간 크게 발생하였지만 전체적으로 말뚝 중심간격이 감소할수록 최대 휨모멘트가 증가하는 경향을 보 여주었다.

사면활동시 말뚝중심간격에 따라 말뚝의 휨모멘트가 증가 하였다는 것은 측방토압이 크다는 것을 의미하며 측방토압이 크다는 것은 말뚝과 말뚝 주변지반 사이의 아칭효과로 인하 여 말뚝의 사면파괴 억지효과가 크다는 것을 의미한다(홍원 표 \& 송영석, 2005). 따라서 말뚝보강 사면에서 말뚝중심간 격이 감소할수록 지진시 사면파괴 억지효과가 증가함을 알 수 있다.

\section{2 .2 최대 휨모멘트 결과}

말뚝두부에 설치된 LVDT를 통해 말뚝두부 수평변위를 측 정하였다. 그림 10 은 말뚝중심간격에 따른 말뚝두부 최대수 평변위를 보여주고 있다. 그림 10 에서 볼 수 있듯이 말뚝 설 치위치가 동일한 경우 말뚝에 발생하는 두부 최대수평변위는 말뚝중심간격이 감소함에 따라 증가하였으며 이는 깊이별 최 대 휨모멘트 결과와 같다. 즉 말뚝보강 사면에서 말뚝중심간 격이 감소할수록 사면파괴 억지효과가 증가함을 알 수 있다.

\section{3 말뚝 설치위치에 의한 영향}

\subsection{1 최대 휨 모멘트 결과}

그림 11 그림 14는 동일한 말뚝중심간격에 대해 말뚝의 설치위치에 따른 깊이별 최대 휨모멘트 결과를 보여주고 있
다. 단말뚝을 제외하고 말뚝중심간격이 $3.33 \mathrm{D}, 5 \mathrm{D}, 6.67 \mathrm{D}$ 인 경우 그림 11 그림 13에서 볼 수 있듯이 말뚝 설치위치 가 상부에서 하부로 낮아질수록 최대 휨모멘트가 증가하는 경향을 보여주었다. 단말뚝인 경우는 그림 14 에 나타난 바와 같이 특정한 경향성을 보이지 않았다. 두부수평변위 결과를 보면 말뚝중심간격이 $3.33 \mathrm{D}, 5 \mathrm{D}, 6.67 \mathrm{D}$ 인 경우와 비교하 여 말뚝두부변위가 작았고, 이로 인해 말뚝에 발생하는 휨모 멘트가 상대적으로 작았기 때문에 단말뚝의 경우 말뚝 설치 위치별 모멘트 결과가 유사하게 나온 것으로 판단된다.

3.2절의 결과는 말뚝의 설치위치가 동일한 조건에서 말뚝 간격을 달리했을 경우에 대한 결과이므로 진동에 의한 지반 의 수평 변위는 각각의 말뚝에 동일하게 작용한다고 볼 수 있다. 그러나 본 절의 경우는 말뚝의 설치위치가 사면의 하

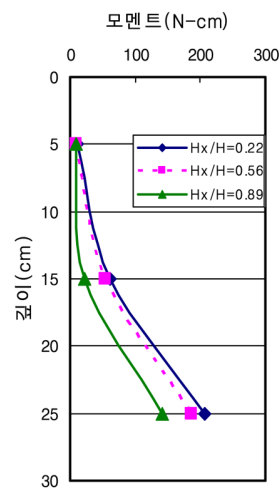

(a) 1 번 말뚝

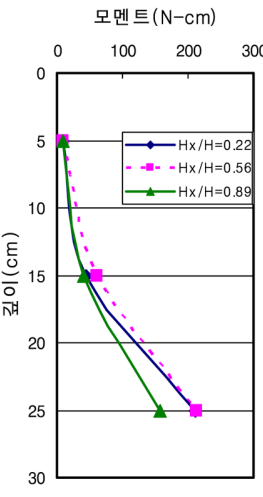

(b) 3 번 말뚝

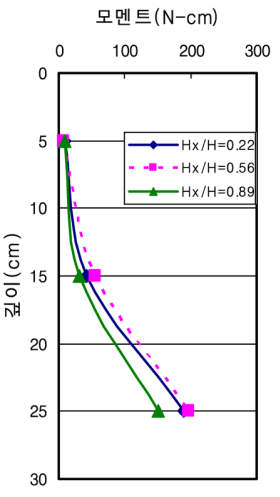

(c) 5 번 말뚝
그림 12. C.T.C. 5D인 경우 말뚝 설치위치에 따른 깊이별 최대 휨모멘트 $(\mathrm{N} \cdot \mathrm{cm})$ 


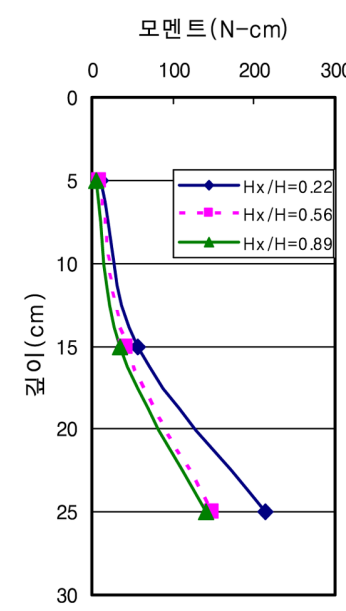

(a) 2번 말뚝

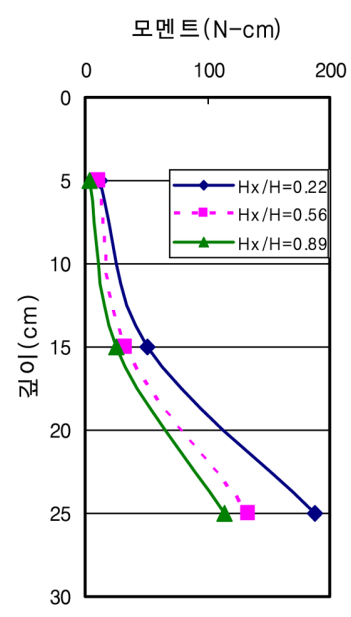

(b) 4 번 말뚝
그림 13. C.T.C. 6.67D인 경우 말뚝 설치위치에 따른 깊이별 최대 휨모멘트 $(\mathrm{N} \cdot \mathrm{cm})$

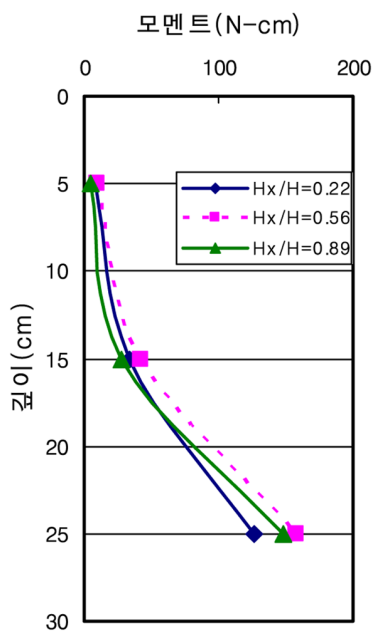

그림 14. 단말뚝인 경우 말뚝 설치위치에 따른 깊이별 최대 휨모멘 트 $(\mathrm{N} \cdot \mathrm{cm})$

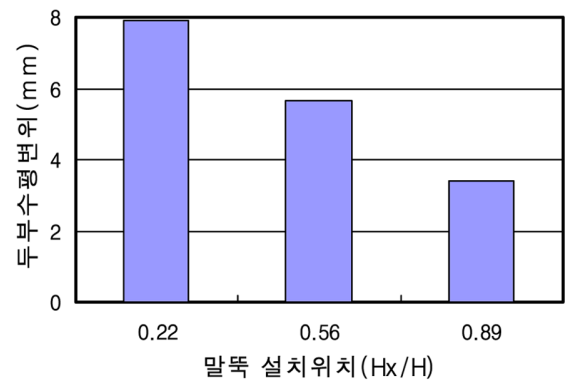

(a) 말뚝중심간격 $3.33 \mathrm{D}$

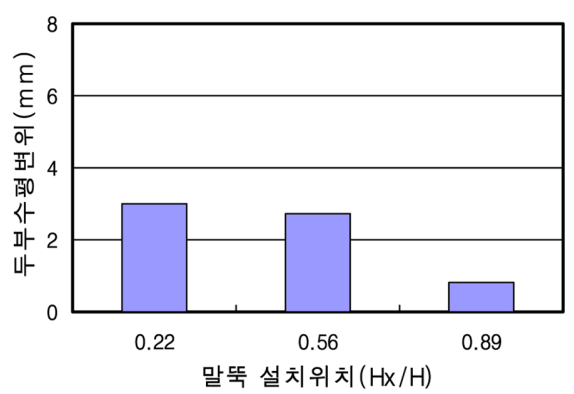

(c) 말뚝중심간격 $6.67 \mathrm{D}$
부, 중앙부, 그리고 상부로 각각 다르다. 즉 같은 중심 간격 인 경우 설치위치가 $\mathrm{Hx} / \mathrm{H}=0.22$ 일 때 최대 휨모멘트가 가장 크다고 해서 3.2절의 결과처럼 가장 큰 사면파괴 억지효과를 보인다고 할 수 없다. 설치위치가 낮아질수록 지반흐름의 양 이 더 많고 흐름속도 역시 크기 때문이다. 따라서 수치해석 을 이용하여 각 말뚝 설치위치에서의 안전율을 계산하고 안 전율 변화를 통해 가장 억지 효과가 큰 설치위치를 알아낼 필요가 있다.

\subsection{2 말뚝두부 수평변위 결과}

그림 15 는 말뚝 설치위치에 따른 말뚝두부 최대수평변위를 보여주고 있다. 그림 15 에서 볼 수 있듯이 말뚝중심간격이 동일한 경우 말뚝에 발생하는 두부 최대수평변위는 말뚝 설 치위치가 상부에서 하부로 낮아질수록 증가하였다. 본 결과에 서도 낮은 말뚝 설치위치에서는 지반흐름의 양이 많아지고 흐름속도 역시 증가하기 때문에 말뚝두부 수평변위가 증가할 수 있다. 따라서 말뚝 모멘트 결과와 마찬가지로 본 결과를 바탕으로 말뚝 설치위치가 낮아질수록 사면파괴 억지효과가 증가한다는 결론을 내리기는 힘들다고 판단된다.

\section{4. 등가정적해석}

\section{1 해석 개요 및 조건}

본 장에서는 $1 \mathrm{~g}$ 진동대 모형실험을 보완하고, 지진시 사면 안정의 목적으로 사용될 억지 말뚝의 적절한 설치위치 및 중 심 간격을 결정하기 위하여 등가정적해석을 수행하였다. 해석 프로그램으로는 실무에서 많이 사용되고 있는 2 차원 사면안 정 해석 프로그램인 TALREN을 이용하였으며, 등가정적해석 을 통해 지진시 억지 말뚝 설치위치 및 중심 간격에 따른 안전율 변화를 살펴보았다. 본 해석에서는 Bishop의 간편법

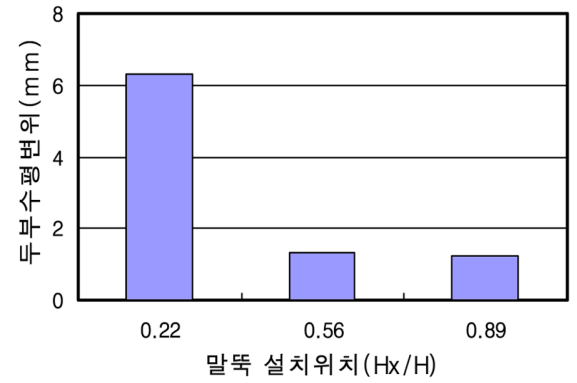

(b) 말뚝중심간격 $5 \mathrm{D}$

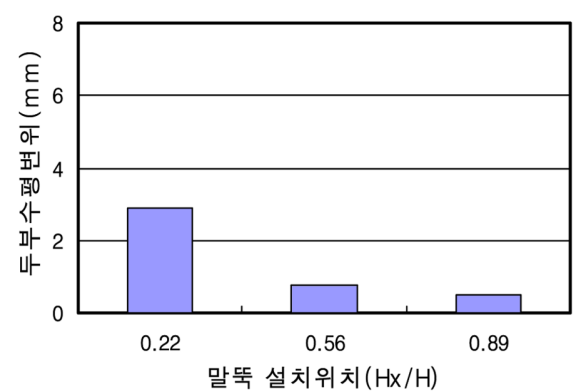

(d) 단말뚝

그림 15. 말뚝 설치위치에 따른 말뚝두부 최대수평변위 
표 3. 해석 조건

\begin{tabular}{|c|c|c|}
\hline \multirow[b]{2}{*}{ 무보강 단면 } & \multicolumn{2}{|c|}{ 억지말뚝 보강 단면 (등가정적해석) } \\
\hline & $\begin{array}{c}\text { 말뚝 설치위치 }(\mathrm{Hx} / \mathrm{H}) \\
\text { 변화 } \\
\text { (C.T.C. 3.33D) }\end{array}$ & $\begin{array}{c}\text { 말뚝중심간격(C.T.C.) } \\
\text { 변화 } \\
(\mathrm{Hx} / \mathrm{H}=0.22,0.56)\end{array}$ \\
\hline $\begin{array}{c}\text { 정적해석, } \\
\text { 등가정적해석 }\end{array}$ & $0.22,0.5,0.56,0.6,0.89$ & $\mathrm{D}, 2 \mathrm{D}, 3.33 \mathrm{D}, 5 \mathrm{D}, 6.67 \mathrm{D}$ \\
\hline
\end{tabular}

을 사용하여 사면안정 해석을 실시하였다. 본 해석에서는 $1 \mathrm{~g}$ 진동대 모형실험 단면 형상을 모사하고자 하였으며, $1 \mathrm{~g}$ 진동 대 모형실험과 마찬가지로 지하수위는 고려하지 않았다.

표 3은 해석 조건을 보여주고 있다. 무보강 단면에 대해서 는 정적해석 및 등가정적해석을 모두 실시하였으며, 억지 말 뚝 보강 단면에 대해서는 표 3에 나타난 바와 같이 말뚝 위 치 및 말뚝 간격을 변화시키면서 등가정적해석을 수행하였다. 우선 말뚝 위치 및 말뚝 간격은 $1 \mathrm{~g}$ 진동대 모형실험에서와 동일하게 말뚝 설치위치 $(\mathrm{Hx} / \mathrm{H}=0.22,0.56,0.89)$ 및 중심 간 격(C.T.C. $=3.33 \mathrm{D}, 5 \mathrm{D}, 6.67 \mathrm{D})$ 을 적용하여 해석을 수행하였 고, 추가적으로 말뚝의 설치위치 및 중심 간격을 변화시켜 안전율 변화를 살펴보았다. 등가정적해석시 필요한 수평지진 계수 $K_{h}$ 는 지표면 최대가속도의 $50 \%$ 를 사용하게 되어있으며, 본 해석에서는 진동대 입력가속도 진폭인 $0.2 \mathrm{~g}$ 를 지표면 최 대가속도로 가정하여 수평지진계수 0.1 을 적용하였다.

해석단면 지층조건은 하부 암반층과 상부 느슨한 사질토층 으로 이루어져 있다. 이에 대한 입력 물성은 기존 문헌에서 제시한 값들의 범위 내에서 합리적으로 선택하였다. 하부 암 반층은 단위중량 $22.5 \mathrm{kN} / \mathrm{m}^{3}$, 마찰각 $40^{\circ}$, 점착력 $147 \mathrm{kPa}$ 으로 가정하였으며, 상부 느슨한 사질토층은 단위중량 $17.64 \mathrm{kN} / \mathrm{m}^{3}$, 마찰각 $30^{\circ}$, 점착력 $4.9 \mathrm{kPa}$ 으로 가정하였다. 본 해석에 사용 된 억지 말뚝은 실제로 많이 사용되고 있는 지름 $406 \mathrm{~mm}$ 의 강관말뚝으로 가정하였으며, 이에 따라 입력 물성값을 계산하 여 본 해석에 적용하였다.

\section{2 해석 결과}

\subsection{1 무보강 사면}

무보강 사면에 대해 정적해석과 등가정적 해석을 수행하였 으며 그 결과는 그림 16 과 같다. 그림 16 에서 볼 수 있듯이
사면 전체에 걸쳐 파괴면이 형성되었으며, 정적해석의 경우 계산된 안전율은 1.08 , 지진하중을 적용한 등가정적해석의 경 우 안전율은 0.9 로 산정되었다. 즉 평상시 안정성을 확보하고 있는 사면이 지진으로 인하여 지반의 관성력이 증가하면 사 면파괴가 발생할 수 있음을 알 수 있다.

\subsection{2 말뚝 설치위치에 의한 영향}

본 절에서는 말뚝중심간격이 $3.33 \mathrm{D}$ 인 경우 말뚝 설치위치 에 따른 사면의 안전율을 등가정적해석 방법으로 산정하였으 며, 그 결과는 그림 17 과 같다. 본 해석에 적용된 말뚝중심 간격 $3.33 \mathrm{D}$ 는 진동대 모형실험시 말뚝중심간격이 가장 좁은 경우에 해당된다. 말뚝 설치위치 역시 진동대 모형실험에서 적용한 $\mathrm{Hx} / \mathrm{H}=0.22,0.56$, 그리고 0.89 를 그대로 적용하였다.

해석 결과 안전율은 말뚝 설치위치가 $\mathrm{Hx} / \mathrm{H}=0.22$ 인 경우 $0.93, \mathrm{Hx} / \mathrm{H}=0.56$ 인 경우 0.97 , 그리고 $\mathrm{Hx} / \mathrm{H}=0.89$ 인 경우 0.92 로 산정되었으며 말뚝 설치위치에 따른 안전율은 그림 18 에 나타난 바와 같다. 또한 파괴면은 말뚝이 사면 하부에 위치한 $\mathrm{Hx} / \mathrm{H}=0.22$ 인 경우는 사면 정점부에서 말뚝 설치위치 까지, 사면 상부에 위치한 $\mathrm{Hx} / \mathrm{H}=0.89$ 인 경우는 말뚝 설치위 치에서 사면 선단부까지 형성되었으며 말뚝이 사면 중앙부에 위치한 $\mathrm{Hx} / \mathrm{H}=0.56$ 인 경우는 사면 전체에 걸쳐 형성되었다. 말뚝이 사면 상부와 하부에 위치한 경우는 그림 17(a)와 그 림 17(c)에서 볼 수 있듯이 말뚝의 억지력으로 인하여 파괴 면은 말뚝이 설치되지 않은 부분에 형성되었다. 이로 인해 파괴면이 말뚝을 관통하는 경우인 말뚝이 사면의 중앙부에 위치했을 때, 사면의 안전율이 가장 크게 산정되었으며 이는 파괴면의 심도가 깊은 사면의 중앙부에 말뚝이 설치되었을 때, 사면파괴 억지효과가 가장 크다는 것을 의미한다.

위의 결과를 통해 지진시 사면파괴 억지효과를 증가시키기 위해서는 억지말뚝을 파괴면의 심도가 깊은 사면 중앙부에 설치해야 함을 알 수 있었으며, 더욱 적절한 말뚝 설치위치 를 알아보고자 말뚝 설치위치를 $\mathrm{Hx} / \mathrm{H}=0.5,0.6$ 으로 변화시켜 추가 해석을 수행하였다. 그 결과 산정된 안전율은 그림 18 에서 볼 수 있듯이 말뚝 설치위치가 $\mathrm{Hx} / \mathrm{H}=0.56$ 일 경우와 같은 0.97 로 변화가 없는 것으로 나타났다. 이는 파괴면의 심도가 $\mathrm{Hx} / \mathrm{H}=0.56$ 일 경우와 차이가 거의 없기 때문인 것으

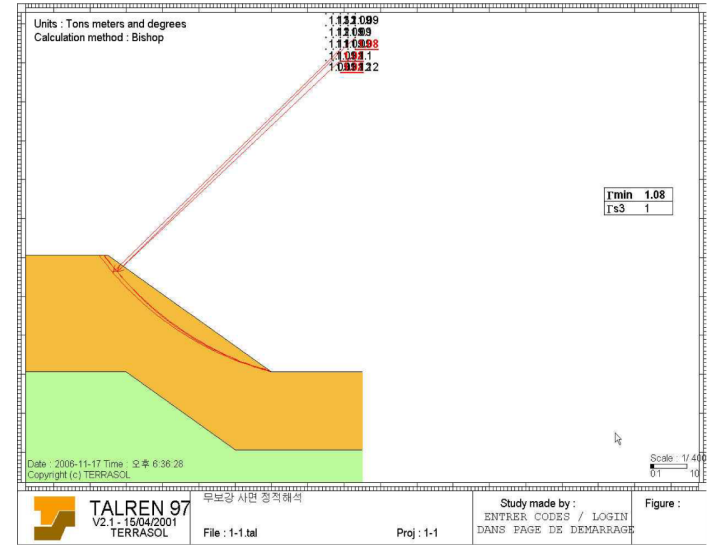

(a) 정적해석

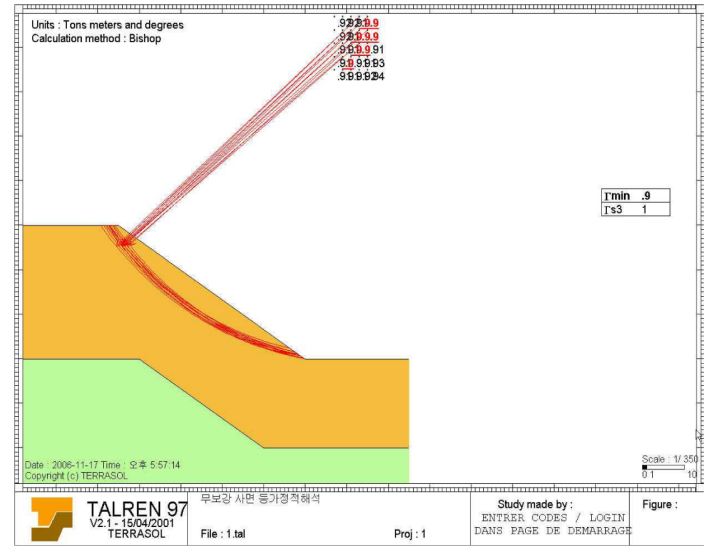

(b) 등가정적해석

그림 16. 무보강 사면안정 해석 


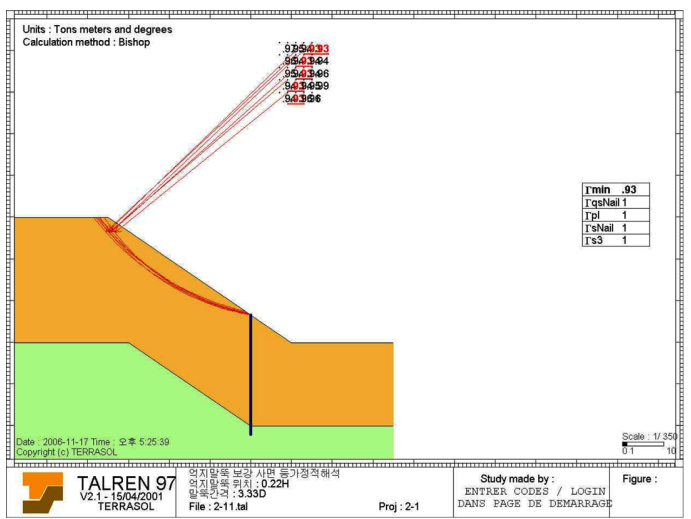

(a) $\mathrm{Hx} / \mathrm{H}=0.22$ (사면 하부)

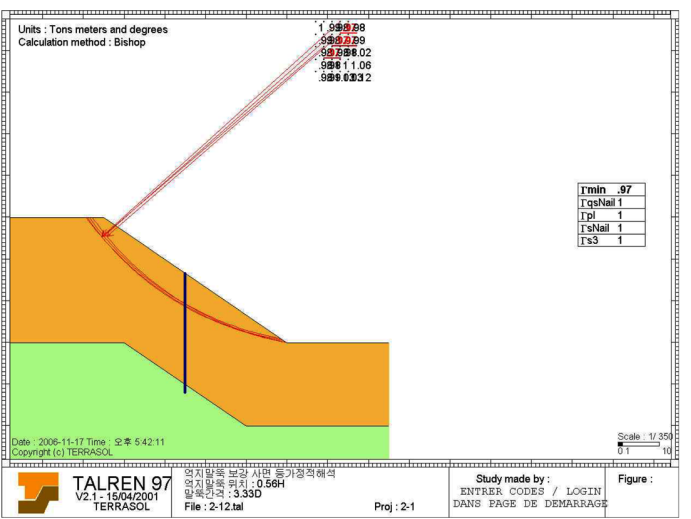

(b) $\mathrm{Hx} / \mathrm{H}=0.56$ (사면 중앙부)

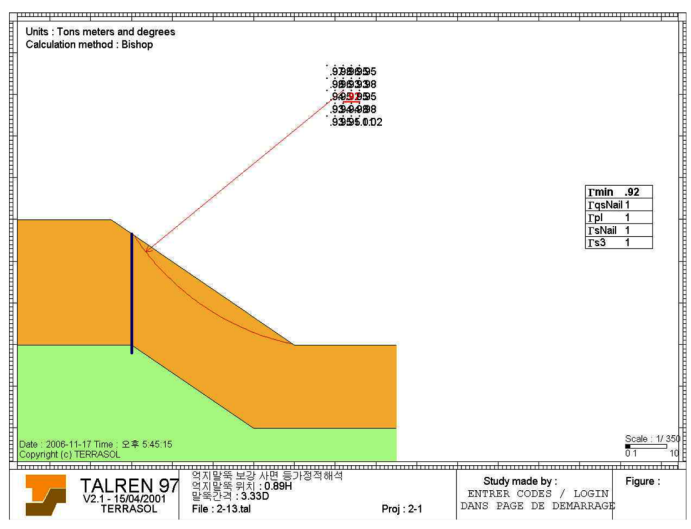

(c) $\mathrm{Hx} / \mathrm{H}=0.89$ (사면 상부)

그림 17. C.T.C. 3.33D인 경우 말뚝설치위치에 따른 파괴면 및 안전율 변화

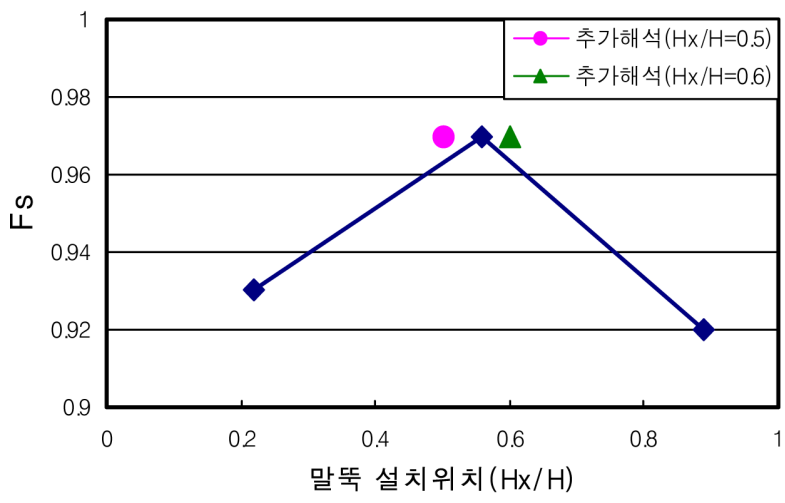

그림 18. C.T.C. 3.33D인 경우 말뚝 설치위치에 따른 안전율

로 판단된다. 따라서, 억지말뚝의 설치위치는 사면안정해석을 통해 우선 사면 파괴면의 형상을 구한 뒤 파괴면의 심도가 가장 깊은 곳으로 예측되는 파괴면의 중앙부가 되어야 할 것 이다.

\subsection{3 말뚝중심간격에 의한 영향}

본 절에서는 말뚝 설치위치가 같은 경우 말뚝중심간격에 따른 사면의 안전율을 등가정적해석 방법으로 산정하였다. 말 뚝중심간격은 진동대 모형실험에서 적용한 $3.33 \mathrm{D}, 5 \mathrm{D}$, 그리 고 $6.67 \mathrm{D}$ 를 그대로 적용하였으며 $\mathrm{D}, 2 \mathrm{D}$ 의 간격도 추가로 적용하였다. 말뚝중심간격에 따른 안전율은 그림 19에 나타 난 바와 같다.

그림 19에서 볼 수 있듯이, 해석 결과 말뚝 설치위치가

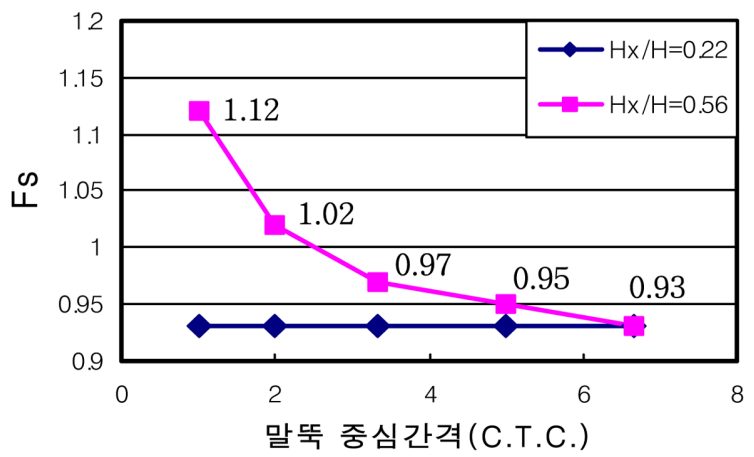

그림 19. 말뚝중심간격에 따른 안전율

$\mathrm{Hx} / \mathrm{H}=0.22$ 인 경우 안전율은 말뚝중심간격에 상관없이 0.93 으 로 동일하게 산정되었다. 이는 앞절에서 설명한 바와 같이 파괴면이 말뚝의 억지력으로 인하여 말뚝과 무관하게 발생하 였기 때문에 말뚝중심간격에 영향을 받지 않은 것으로 판단 된다. 따라서 파괴면이 말뚝을 포함하지 않는 $\mathrm{Hx} / \mathrm{H}=0.89$ 인 경우도 말뚝중심간격에 따른 안전율 변화가 없을 것으로 판 단된다. 파괴면이 말뚝을 포함하는 $\mathrm{Hx} / \mathrm{H}=0.56$ 인 경우, 안전 율은 말뚝중심간격이 $6.67 \mathrm{D}$ 인 경우 $0.93,5 \mathrm{D}$ 인 경우 0.95 , $3.33 \mathrm{D}$ 인 경우 $0.97,2 \mathrm{D}$ 인 경우 1.02 , 그리고 $\mathrm{D}$ 인 경우 1.12 로 말뚝중심간격이 감소함에 따라 증가하였다. 즉 중심 간격 $6.67 \mathrm{D}$ 를 기준으로 했을 경우 중심 간격이 $25 \%, 50 \%$, $70 \%$, 그리고 $85 \%$ 감소함에 따라 안전율은 각각 $2.2 \%$, $4.3 \%, 9.7 \%$, 그리고 $20.4 \%$ 증가하였다. 사면의 파괴면이 말 뚝을 포함하는 $\mathrm{Hx} / \mathrm{H}=0.56$ 인 경우 말뚝의 중심 간격이 감소 
함에 따라 안전율은 증가하였으며, 이는 말뚝중심간격이 감소 할수록 말뚝 사이의 지반의 측방변위가 더욱 제약을 받는다 고 할 수 있다.

\section{5. 결 론}

본 연구에서는 $1 \mathrm{~g}$ 진동대 모형실험 및 TALREN을 이용 한 등가정적해석을 통하여 지진시 억지말뚝이 적용된 사면 및 억지말뚝의 지진시 거동을 분석하고 사면의 내진 보강공 법으로써 억지말뚝의 적용성을 평가하고자 하였다. 본 연구를 통하여 얻은 결과를 정리하면 다음과 같다.

1) $1 \mathrm{~g}$ 진동대 모형실험을 통해 말뚝보강 사면의 사면파괴 억지효과를 알아보기 위하여 진동전후 무보강 사면과 말 뚝보강 사면의 사면경사 변화를 분석하였다. 그 결과 진 동후 무보강 사면의 경사는 진동전과 비교해 $44 \%$ 감소 하였으며 말뚝보강 사면의 경우 $32 \%$ 감소하여 말뚝보 강 사면의 사면파괴 억지효과를 검증하였다.

2) $1 \mathrm{~g}$ 진동대 모형실험을 통해 말뚝보강 사면인 경우 말 뚝의 중심 간격 및 말뚝의 설치위치가 사면파괴 억지효 과에 미치는 영향을 분석한 결과, 동일한 말뚝 설치위치 에서 말뚝중심간격이 감소할수록 말뚝에 발생하는 최대 휨모멘트와 두부수평변위가 증가함을 알 수 있었으며 이 는 말뚝과 말뚝주변지반 사이의 아칭효과 때문으로 판단 된다. 따라서 말뚝중심간격이 감소할수록 사면파괴 억지 효과가 증가함을 알 수 있었다. 또한, 동일한 말뚝중심 간격에서 말뚝 설치위치가 사면 하부로 낮아질수록 말뚝 에 발생하는 최대 휨모멘트와 두부수평변위가 증가하는 경향을 나타내었다. 그러나, 이는 사면파괴 억지효과와 더불어 지반흐름의 양과 흐름속도가 증가하여 발생한 결 과이므로, 진동대 모형실험을 통해 사면 하부에 말뚝을 설치한 경우가 사면 파괴 억지 효과가 가장 크다고 판 단하기에는 무리가 있다.

3) 무보강 사면에 대해 정적해석과 등가정적 해석을 수행한 결과 정적해석과 등가정적해석으로 계산된 안전율은 각 각 1.08 과 0.9 였으며, 이를 통해 평상시 안정성을 확보 하고 있는 사면이 지진으로 인하여 지반의 관성력이 증 가하면 사면파괴가 발생할 수 있음을 보여주었다.

4) 말뚝중심간격이 $3.33 \mathrm{D}$ 인 경우 말뚝 설치위치에 따른 사면의 안전율을 등가정적해석 방법으로 산정하였다. 그 결과 말뚝이 사면의 중앙부에 위치했을 때 사면의 안전
율 0.97 로 가장 크게 산정되었다. 이는 파괴면이 말뚝을 포함하지 않는 사면 하부와 사면 상부와 달리, 사면의 중앙부에 말뚝을 설치하였을 경우 파괴면이 말뚝을 관통 하며 안전율을 증가시켰기 때문으로 판단된다. 따라서, 억지말뚝의 설치위치는 사면안정해석을 통해 우선 사면 파괴면의 형상을 구한 뒤 파괴면의 심도가 가장 깊은 곳으로 예측되는 사면 파괴면의 중앙부가 되어야 할 것 이다.

5) 말뚝 설치위치가 같은 경우 말뚝중심간격에 따른 사면의 안전율을 등가정적해석 방법으로 산정하였다. 그 결과 말뚝 설치위치가 사면 하부인 경우 말뚝의 억지력으로 인하여 파괴면이 말뚝과 무관하게 형성되었기 때문에 안 전율은 말뚝중심간격에 상관없이 0.93 으로 동일하게 산 정되었다. 말뚝 설치위치가 사면 중앙부인 경우 중심 간 격 $6.67 \mathrm{D}$ 를 기준으로 했을 때 중심 간격이 $25 \%, 50 \%$, $70 \%, 85 \%$ 감소함에 따라 안전율은 각각 $2.2 \%, 4.3 \%$, $9.7 \%, 20.4 \%$ 증가하였다.

\section{참고문헌}

대한주택공사 (1999) 대한주택공사 토목구조물 내진설계지침. 송영석 (2004) 활동억지시스템으로 보강된 사면의 설계법, 중앙대 학교 일반대학원 박사학위논문, pp. 317-327.

이승호 (2005) 억지말뚝 근입깊이 및 배치간격에 따른 사면 안전 율 변화에 관한 연구, 한국지반공학회논문집, 제 21 권, 1 호, pp. 115-121.

정상섬, 유광호, 이선근 (2003) 억지말뚝-사면의 상호작용 효과, 한국지반공학회논문집, 제 19권, 5호 pp. 163-173.

한국지반공학회 (2006) 지반구조물의 내진설계.

홍원표, 한중근, 송영석, 신도순 (2003) 대절토사면에 보강된 억 지말뚝의 활동억지효과에 관한 연구, 한국지반공학회 사면안정 학술발표회 논문집, pp. 65-81.

홍원표, 송영석 (2005) 사면에 설치된 억지말뚝의 활동억지효과에 대한 실험적 연구, 한국지반공학회논문집, 제21권, 1호, pp. 69-80.

Ito, T., Matsui, T. and Hong, W.P. (1981) Design method for stabilizing piles against landslide-one row of piles, Soils and Foundations, Vol.21, No.1, pp. 21-37.

Ito, T., Matsui, T. and Hong, W.P. (1982) Extended design method for multi-row stabilizing piles against landslide, Soils and Foundations, Vol.22, No.1, pp. 1-13.

() 논문접수일 : 11년 02월 22일 (9) 심사의뢰일 : 11 년 03월 07일 (C) 심사완료일 : 11년 03월 14일 